Мирослав Перишић Архив Србије, Београд perisic59@gmail.com
930.85(=163.41)(450.361)"17/18" https://doi.org/10.18485/ai_most.2017.ch6

\title{
СРПСКО ГРАЋАНСТВО У ТРСТУ \\ И „БАЛКАНСКИ ТРОШАН СВЕТ“: \\ МОСТ КА ДУХОВНОЈ И ДРЖАВНОЈ ОБНОВИ СРБИЈЕ У 18. И 19. ВЕКУ
}

У раду се анализира настанак и развој српског грађанства у Трсту у периоду док се Србија још увек налазила под турском влашћу и утицај Трста као духовног средишта Срба ван Србије, односно Срба у Трсту на духовну а касније и државну обнову Србије. Рад садржи и својеврсну периодизацију значаја Трста за историју Србије посебно у 18. и 19. веку односно три компоненте: очување верског и културног идентитета, јачање националног идентитета и политички значај Трста за спољну политику Краљевине Србије.

Кључне речи: Трст, Срби у Трсту, српско грађанство у Трсту, верски идентитет, економска моћ, помоћ српским манастирима и црквама, помоћ устаницима против турске власти, Генерални конзулат Краљевине Србије у Трсту, политички значај Трста за Краљевину Србију

У српској култури и научној историографији Трст је у историјском смислу одавно препознат као једно од најзначајнијих духовних средишта Срба посебно у другој половини 18. и током 19. века. На основу сачуваних писаних трагова, посебно и највише на основу докумената из Архива Српске православне црквене општине у Трсту, као и на основу целокупног српског културног наслеђа у 
Трсту познато нам је да су први Срби у потрази за послом, пре свега трговином, почели да се досељавају у Трст још у првој половини 18. века, да су временом у том граду аустријске царевине почели да стварају своју заједницу, да су формирали српску православну црквену општину, да су изградили неке, и данас, од најлепших грађевина, да су се почетком 19. века, посебно од избијања, а потом и у току, Првог српског устанка, у Трсту окупљали угледни Срби који су материјално и духовно помагали борбу за национално ослобођење.

Духовно и материјално наслеђе Срба у Трсту ту заједницу у историји чини већом него што је она по својој бројности била. О томе знатно дуже од једног века упечатљиво сведоче њихова градитељска достигнућа сачувана у урбаном језгру Трста. Данашњи Трст би тешко било замислити без Храма Светог Спиридона у срцу града и без здања која су у 18. и 19. веку саградили или купили богати Срби, тик уз Велики канал (Canale Grande), на тргу Понте Poco (Ponte Rosso), у Ђузепинској и Франческанској четврти, на риви Пескатори која данас носи назив Рива Сауро и у делу града око Јозефовог трга који данас носи назив Трг Венециа (Piazza Venezia). Према наводима Марианђеле Албанезе у књизи Светилости и сенке, Срби у Трсту су били власници више од шездесет зграда, а да је сасвим реално да их је у њиховом поседу било и до стотину. У најимпресивнија здања спадају она која се у литератури препознају по називима палата: Гопчевић, Бајовић, Вучетић, Ивановић, Ковачевић, Куртовић, Поповић, Рађенковић, Цвијетовић, Чевезић, Шкуљевић. Пажњу проучавалаца привлаче и куће породица Ризнић, Бота, Николић, Теодоровић, Паликућа, Дабовић. Историјском наслеђу Срба у Трсту припада и палата италијанског назива Stella polare ca „типичном бечком кафаном“ у приземљу, на углу данашњих улица Алигијери (Alighieri) и Ђенова (Genova), 
некада месту окупљања писаца и трговаца, па самим тим и неког посебног шарма, увек привлачног начина друштвеног живота, са неизбежним билијаром, салом за састанке и читаоницом у свом саставу. У суседству Stella polare je Кућа српске заједнице - још једно градитељско наслеђе у којој су смештени Српска православна црквена општина, Архив Српске православне црквене општине, Библиотека Српске православне црквене општине и Српска школа „Јован Милетић“, основана још 1793. године капиталом задужбинара чије је име понела.

Присуство Срба у Трсту било је најзапаженије у 18. и 19. веку, управо у раздобљу када је цветала трговина а град доживљавао свој уобличавајући преображај под доминантним утицајем средњоевропске градитељске културе која се у оквиру Хабзбуршке монархије спуштала од севера ка југу. Трст је крајем 18. и посебно у 19. веку био велико градилиште; солане су уступале место палатама и црквама; прокопаване су улице и осмишљавани тргови; архитекте, градитељи, каменоресци и занатлије разних заната су имали пуне руке посла, а сликари украсног сликарства опробавали свој уметнички дар на таваницама пространих улаза и широких степеништа здања на три спрата колико је било дозвољено да се гради. Градови који имају море обично су „стопљени“ са њим, прате његове обале. У Трсту је другачије. Још тада је осмишљено да море широким каналом улази дубоко у град.

Градитељство је за богате породице и појединце, осим интереса капитала, доносило лични престиж и било вид уздизања на скали економске и друштвене моћи. Најлепше зграде у Трсту у које свакако спадају и оне које су богати Срби, будући да су били укључени у историјске токове града, изградили или купили, својеврсни су представници историјског раздобља које се у историји Трста с правом тумачи као прекретничко. Осмишљаване су са идејом да трају и грађене као остварење амбициозних 
снова. О њиховим некадашњим власницима може се мислити као о разметљивим људима, јер грађевине су у дужину могле да буду и за коју десетину метара мање и опет би на простору на коме су никле деловале велелепно, али упућенији у историју знају да је град отет од мора, да је простор који се на тај начин отворио омогућио архитектонски и градитељски размах и да је деловима града где се завршава море дао смисао и лепоту која осваја док се посматра. Та лепота није само архитектонска и уметничка. У њу је загледан сваки љубитељ прошлости, човек који гледа кроз перспективу историје; она пружа ону димензију прошлости коју људи воле, јер на основу ње некадашња стварност изгледа лепо, богато и моћно.

Тршћанским старим здањима време није ништа узело од њихове лепоте. Ничег у ономе што је тада урбанистички обликовано нема дотрајалог или застарелог у духу и приликама времена. Зидове палата време није потрошило. За то је заслужна каснија култура која је неговала наслеђено, али и чињеница да су у градитељске подухвате укључивани велики мајстори оног времена, искусне архитекте и уметници који су доприносили да настану далекосежна дела када се на будућност мислило и када се она лепо сањала. Култура односа према култури прошлости одржала је град у његовом сјају упркос свакојаким кризама које су с времена на време, посебно у 20. веку, пресецале историјске токове развитка. Моћ и богатство прошлости су ишчезли, али са њима није нестала култура прошлости. Заборав није победио културу памћења. Деветнаестовековно није рушено нити ружено у наредном веку и на његовом месту није грађено у интересу неког новог капитала који не мари за традицију.

Трст је град постојане лепоте. Оно што је некада било лепо и данас је лепо. Историје је на сваком кораку, она се поштује, срасла је са данашњицом, не оптерећује 
садашњост, као што ни у време када је она стварана њој њена претходна историја није била препрека. Напротив, оно што је претходило омогућило је оно што је уследило, а оно што је уследило говори о ономе што је претходило. Вероватно је и то један од разлога што је данашњи Трст град који не умара. Кроз историју је испољио велику способност и да прихвата и да даје. Није настао на насиљу, као што је случај са градовима који су се богатили на плену пљачкашких освајачких похода џиновских империја. Формирао се и развијао на слободама које је кроз историју уживао и пружао. Све то има велике везе са садашњошћу и идејом културе, корачању у сусрет изазовима тржишта, образовања и стваралаштва, као и умећем живљења које негује тршћанска свакодневица. Многим данашњим предностима Трста - не свим - корене треба тражити у прошлости. Култура је, уз економију, несумњиво била свепрожимајући чинилац настанка и развитка овог модерног града. Културе су се сусретале и свака је задржавала своју индивидуалност: поред и наспрам здања саграђених у духу средњоевропског културног утицаја уздижу се изнад кровова Терезијанског кварта српска православна Црква Светог Спиридона, католичка Црква Светог Антуна и с погледом на море грчка православна црква; са очуване Тврђаве Сан Ђусто погледом се доминира градом; на фасади Палате „Гопчевић“ пажњи не могу да измакну камене фигуре цара Лазара, царице Милице, Милоша Обилића и Косовке девојке; у градском музеју (Civici Musei di Storia ed Arte) чува се портрет краљице Наталије у природној величини; ирском књижевнику Џемсу Џојсу, који је део живота провео стварајући у Трсту, град се одужио спомеником - пишчева фигура у ходу изливена у бронзи на мосту Ponte Rosso и плоча са које се чита „...la mia anima

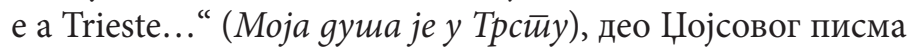
супрузи Нори 1909. године; Универзитет је стециште 
страних студената; архиви, музеји, галерије, позоришта - места у која се залази по дубље разумевање историје и мултикултуралности града.

Свој идентитет град је развијао на мултиетничности, писци га описују као космополитски, највише италијански, германски и словенски, град са традицијом учења страних језика. Отвореност према спољном свету, са истрајавањем да се буде другачији, учинили су да Трст заиста буде различит и ту своју различитост Тршћани љубоморно чувају. Турска освајања до њега нису допрла да би се поисточњачио, није до краја ни позападњачен, не може се сматрати средњоевропским упркос богатом средњоевропском културном наслеђу, а то што је највише италијански ипак није у довољној мери да би личио на остале италијанске градове. При свему томе треба имати у виду да Трст није заточеник прошлости. Трст никада у својој историји није био славан попут појединих градова којима је историја доделила славу, а онда им је узела. Бити славан, а потом живети од старе славе без перспективе није судбина овог града. У Трсту се не пати ни од идеје мењања света. Историјско искуство Другог светског рата са насилном, нечовечном идеологијом, рођеном у Италији, која је уздрмала човечанство, претешко је да би се призивала велика историјска збивања.

Трст је кроз историју био вишеструко гранични град; граница копна и мора, Медитерана и Балканског полуострва, Хабзбуршке монархије и Краљевине Италије, капитализма и социјализма. У његовом непосредном залеђу спуштала се гвоздена завеса која је у политичком смислу раздвајала светове и до које је допирала најзападнија тачка социјализма, а тиме и Истока у хладноратовској епохи. Гледано са Истока, Трст је био капија за Запад, а гледано са Запада излог према Истоку; дуго је био и капија Хабзбуршке монархије за излаз на море. Најзад, изнад Трста је и најзападнија тачка словенског света. 
Трст је и гранични град различитих култура. На само неколико километара од града, када се изађе из Опићине и уђе у Словенију, није само небо другачије, већ и менталитет, примећује се другачији начин живљења, а све се на први поглед уочава по начину одевања.

O томе како ће да изгледа и како ће у њему да тече живот размишљало се визионарски у време Карла VI и Марије Терезије. У прва три века аустријске владавине, почев од 1382. године, није се ништа значајније догађало у историји града, да би најпре 1719. године Карло VI прогласио Трст за слободну луку, а потом 1740. Марија Терезија извршила реорганизацију монархије централизацијом државе, укидањем пореских препрека између провинција и стварањем управних органа, што је Трсту удахнуло нови живот. Започело је стварање темеља за настајање модерног и економски богатог града; на заравни испод Сан Ђуста почела је изградња новог града који је данас његов централни део и носи назив Терезијански кварт. Трст од тада више није личио на време када је живот био концентрисан на Сан Ђусту, град доживљава трговински и финансијски успон, оснивају се бродоградилиште, бродске компаније, осигуравајућа друштва, све је више предузимљивих појединаца, људи се запошљавају, значајно се увећава број становника, тршћанска Трговачка комора израста међу најкрупније акционаре за изградњу Суецког канала, а по њеном потпредседнику барону Пасквале Револтелу данас носи назив један од бројних музеја у Трсту. Вођена својим интересима, Хабзбуршка монархија се према Трсту у том раздобљу односила као према свом чеду које јој омогућује излазак на Средоземље, чини јој ближим источна тржишта и обезбеђује јој погодности за јачање војне поморске моћи. Хабзбуршки сан о својој вечитости, што није ништа необично за царства која увек размишљају у вековима и моћним категоријама, имао је, када је реч 
о Трсту, као последицу рађање нове урбане структуре града са истанчаним осећајем за простор. Захваљујући тадашњим урбаним решењима град је постао близак човеку и приступачан и са копна и са мора на начин да делује као да се спушта до човека, савија око њега, прилагођен му је учинивши живот једноставнијим и својом једноставношћу хуманијим. Мрежа улица грађених под правим углом омогућује лакоћу кретања и дубок видик. Не постоји једна главна улица, као да су све главне; споредне нису лишене пажње и садржаја, док се забаченији делови града, да поменемо и њих, заправо не могу сматрати забаченим, већ само удаљенијим, безлични су, али не и тужни, сиромашни и руинирани. На рубним деловима града нема оних непристојно неомалтерисаних нових кућа без плана и укуса, каквих је у великом броју широм знатног дела Балкана.

Импресије о Трсту не зависе од посматрача. Све је некако дато, ништа не изискује посебну посматрачку способност да би се лепо видело и доживело; колико год пута се спољашњи посматрач у току једног дана нашао на истом месту оно му не бива досадно, угао гледања скоро да је небитан, отменост и лепота затичу тек пошто се претходни поглед одвоји са нечег такође отменог и лепог, па се појединац зачас нађе у улози загледаног поштоваоца оног што види пред собом, а које га, на неки миран и истовремено узбудљив начин, изазива да упија очима, да то што види упамти и заволи, да поново пожели да види. Историја која се гледа, осећа и сазнаје, Трст чини привлачним местом, као што је и све друго у њему пријајуће; и култура живљења и становања, и култура одевања и храна, и клима и поднебље, и традиционални смисао за естетско. Трст је град лепоте обичног у људском животу. Све је некако једно с другим у складу. У њему влада нека равнотежа између историје и садашњости, између појединца и града, улица и тргова, палата, кућа и вила, таласа 
мора и алпских урвина, поднебља и тла, између љубави према старинама и љубави према моди. Као да се догодило сједињавање енергије природе, која је у непосредној околини сва у контрастима, са енергијом људи и као да је ова прва утицала на ову другу.

Наравно, мало шта од тога би деловало тако складно и тако опуштајуће и тако другачије да се ту на лицу места, у институцијама, на пјацама, раскршћима улица, у кафеима, а не само на Универзитету, у литератури, уметности и другим врстама стваралаштва, не осећа дух града. Трст је град умећа живљења. И сав је Трст налик замишљеној слици на којој је уметник тематизовао склад природе и човека, неба и земље, дарове природе и дела човекових руку и његове маште која је осмислила да се и трамвај са Опићине креће напорнијом трасом само зато да у један поглед стану и град и море.

У Трсту ништа није црно-бело, сав је град разнобојан, подсликан у бојама мора, неба, шуме, траве, песка... На неки посебан начин зрачи. Већ после дан или два човек са стране облачи се као Тршћанин, лако прихвата навике тршћанске свакодневице и осећа да је саставни део средине. Ипак, каквим год поводом и колико год пута био у Трсту остаће му нејасно колико је Тршћанима стало до тога шта странац мисли о њиховом граду. Они су град кројили по својој мери, удешавали по својој естетици и својим образовним, културним и свакодневним животним потребама и задовољствима, да њима буде лепо и да град њима прија, а како ће га доживети странац, зависи од њега самог. Наспрам такве врсте неке релативне равнодушности или привида равнодушности према мишљењу странца о њиховом граду, у свему осталом они ће показивати колико им је стало до уважавања човека са стране. Научник и универзитетски професор ће ca изузетном предусретљивошћу и ненаметљивошћу разговарати на озбиљне теме са страним колегом, показати 
висок ниво културе слуха и бити спреман на сарадњу; архивиста и музеалац ће радо да одвоји време за љубитеља прошлости или професионалног истраживача; тршћански продавац је познат по томе што ће својски да се труди да погоди укус муштерије, помогне и у избору, предложи комбинације, моделе и боје, чинећи све да оног ко је закорачио у његову радњу задржи што дуже. Најзад, Баратоло (Barattolo), ресторан где се служе специјалитети поднебља и домаће вино bianco увек поправља расположење колико год оно и пре тога било добро. Увек има пуно људи, а разиграно особље ће изненађивати намернике када однекуд доноси нове столове и ређа их на тротоару у недоглед, све до Цркве Светог Антуна, за којима ће се изузетно сместити и до пет стотина гостију. Лишена сваког луксуза, са пластичним столовима и столицама, на једној од најлуксузнијих локација, башта Баратола одмара поглед на све четири стране: дуж Canale Grande према мору, према Цркви Светог Спиридона, према Цркви Светог Антуна или ка тротоару, ту на метар-два, који више личи на модну писту за све генерације него на једну од пролазних путања ка обали мора. Као да је све удешено да прија.

Наспрам овог „култног“ места, далеко од очију јавности, а близу очију истраживача, на другом спрату Куће српске заједнице, која се наслања на цркву Светог Спиридона, а део је комплекса зграда Српске православне црквене општине, прозорима окренута ка Тргу Светог Антуна, у броју 7 налази се историја Срба у Трсту сачувана у документима Архива Српске православне црквене општине. Сачувана је захваљујући свести ондашњих далековидих Срба који су још 1793. године установили правила о уредном вођењу документације, што је омогућило касније формирање Архива Српске православне црквене општине. Највише онога што знамо о историји Срба у Трсту је захваљујући тој архивској грађи, посебно 
Српско грађанство у Трсту и „балкански трошан свет“... 121

оној која се чува у оквиру „Старе архиве“ (Vecchio Archivio). Тако се оно што је од историје у Трсту оку видљиво допуњује оним што се у документима чита.

Писати о граду не значи писати само лепо. Ипак, о Трсту се увек писало лепо. Како ће неко писати о граду, а да то није само историја, већ му историја служи за дубље разумевање данашњег, зависи и од тога шта очекује од града и са чим га упоређује. У Трсту је, рецимо, све супротно Истанбулу у опису Бродског. И у Трсту је све старо, али није устајало.

Трст је у литератури саткан од поетских израза, књижевних углова посматрања, уметничких сликања, историјских студија. Над том литературом лебди једна необична појава. Она побуђује осећајност која заједно са живим сликама тршћанских призора и његове панораме даје снагу личном доживљају. Тако лични доживљај дубок и упечатљив, памтљив и непролазан постаје део искуства историчара за које се не би могло рећи да је варљиво. Оно историчару олакшава сналажење у архивима.

А архиви? Они сведоче да су Трст одувек волели и походили владари, духовници, песници, књижевници, историчари, уметници, трговци и сасвим обични људи.

Своју отвореност за спољни свет Трст је развио доста рано у својој прошлости. Томе су несумњиво доприносили географски положај и сама историја града. С једне стране, благе зиме и подношљива лета Трст чине пријатним местом за живот и разне послове, а с друге његова историја је у односу на бројне друге европске просторе имала релативно мирне токове. Према једном опису с краја 19. века зимске температуре нису падале испод шест, а највише летње су биле нешто изнад тридесет степени ${ }^{1}$. Климатски услови резултат су сусретања

1 АС (Архив Србије), МИД, ПО, Ф. ІІІ, И/13. - Извештај Краљевског српског вицеконзула у Трсту, Марка Мариновића, 10. јули 1889. 
медитеранских ваздушних струја са онима што пристижу са Јулијских Алпа, чије урвине допиру до надомак града. У истом опису, тршћанска територија била је некада под густим шумама, а временом су нестале, услед непажње самих житеља и зато што су током ратова руком непријатеља биле посечене, да би у другој половини 19. века организованим залагањем Тршћана било засађено под шумом око 150 хектара најнеплоднијег земљишта у непосредном залеђу ${ }^{2}$. По свом географском положају, посматрано из угла Хабзбуршког царства под чијом заштитом и управом се налазио од 1382. до 1918. године, са кратким прекидима у 19. веку, када је у два наврата долазио под француску власт, Трст међу осталим градовима није имао супарника.

У литератури је забележено да су становници Трста већином били пореклом из Венета, Истре, Фриулија, Крањске области, Горице, Фераре, Мантове, Модене, Милана, Ђенове, затим из Црне Горе, Босне и Херцеговине, Далмације, Грчке и Турске. Трст је у 18. и 19. веку, а то је управо раздобље и када се учешће Срба у привредном животу и урбанистичком преображају града најснажније испољило, доживљавао значајан економски успон. Изузев у кратким периодима француске окупације, Трст је готово од самог почетка 18. века уживао економске погодности, које је аустријско царство, следећи своје привредне и геостратешке интересе, доделило Трсту, а касније их из истих разлога Аустроугарско царство одржавало. У време када се прва генерација Срба досељавала у Трст, средином 18. века, овај град је за људе са Балкана био прибежиште и заклон од османлијске власти која је на просторима са којих су се Срби досељавали господарила путевима и тржиштима. Истовремено, за ту, и касније генерације Срба у Трсту било је то склањање од тешке колективне судбине која је задесила српски народ

Исто. 
Српско грађанство у Трсту и „балкански трошан свет“... 123

падом под турску власт. За пословне људе са Балкана, пре свега трговце и морепловце, Трст је био и привредна и животна средина која је пружала могућности за уносне послове и породичне планове за дуго време. Од времена пада под турску власт српски народ није био у могућности да одлучује о сопственој будућности. У дугом историјском раздобљу налазио се на рубовима двају царстава - Хабзбуршког и Османлијског, што је значило, прихватимо ли Броделову поделу на спољашње и унутрашње ратове, да се налазио на удару спољашњег рата, односно рата између хришћана и муслимана, и зато је више пропатио од народа који су се географски налазили у дубљем хришћанском простору. Ако се упореде судбине простора и успостави најопштија хронологија догађаја, уочићемо колике су разлике у историјским токовима Балкана и Трста. Док се у Трсту од доласка под заштиту Аустријског царства 1382. године, па у наредних три века, није ништа значајније догађало, на Истоку су се ређали драматични догађаји балканске и европске историје: пад Бугарске под турску власт, Косовска битка, пад Цариграда, Атине, Смедерева, Београда, Будима, Босне, Херцеговине, Скадра, Драча... После Косовске битке хиљаде Срба је било продавано као робље на пијацама, а у Босни је после турског освајања дошло до масовног преласка у ислам.

Одлазак Срба са немирног балканског простора у Трст у 18. веку био је вишеструко мотивисан. Било је то својеврсно померање иако малобројних, ипак финансијски моћних појединаца и породица, од Истока ка Западу и прелазак из једног света у други, из једне цивилизације у другу. Остављајући иза себе „трошан балкански свет“ препун препрека за послове и спокојан живот, у Трсту су нашли уточиште које им је обезбеђивало слободу, могућност за трговину, стицање материјалних добара, богат живот, будућност за потомке. Од времена њиховог досељавања у Трст започела је вишевековна континуи- 
рана историја Срба у Трсту с тим да је значајније учешће Срба у друштвеном и привредном животу тог града ипак ограничено на период нешто дужи од једног века. У том временском раздобљу Срби у Трсту су израсли у заједницу која је била битан саставни део историје тог града. Више чинилаца и догађаја обележили су историју српске заједнице у Трсту међу којима су најзначајнији: повољан социјално-економски амбијент за трговину, морепловство, бродоградњу и градитељство, пореске привилегије које је Хабзбуршка монархија доделила Трсту, слобода вероисповести и оснивање Српске православне црквене општине, оснивање Српске школе, непосредне везе са водећим личностима српског књижевног и политичког живота, помоћ српским устаницима у борби за национално ослобођење, градња прве, па затим друге српске православне цркве, учешће у урбаном развоју града изградњом великог броја палата у централним зонама Трста. Оно што османлијска власт није успела са овим успешним и предузимљивим Србима, успела је својим умећем владања Хабзбуршка монархија. Трст је Србима омогућио да постану богати лојални припадници монархије и да развијају послове на своју и њену корист. Истовремено, омогућено им је да задрже своју верску и националну индивидуалност, односно да постану саставни део једне прожимајуће културе задржавајући део националне културе и свести. Свој идентитет више су чували посредством вере и њеног практиковања него преко језика и културе, тако да је њихова побожност била свепрожимајући чинилац у очувању верске припадности и неговања националне свести. Приближили су Србију Западу. Радован Самарџић је писао да су Срби у Трсту били посредници између западне културе и Балкана. Они су заправо помогли утемељивање националне културе у времену када су Балкан и Србија улазили у постосманско доба отварањем према 
Српско грађанство у Трсту и „балкански трошан свет“... 125

европској култури. За посматраче тршћанских прилика, Срби у Трсту су били људи који су припадали народу без државе. Живели су у граду који је повећавао пословне способности и омогућавао трговачке и друге комуникације на велике удаљености, односно везе са далеким тржиштима, стицање већег профита, нарастање пословних амбиција и идеја, а све то опет омогућавало је да буду укључени у историјске токове и да преузимају одређене националне задатке. Са представницима српског књижевног и политичког живота који су се окупљали у Трсту могли су да разговарају о покренутим питањима судбине српског народа под турском влашћу у стремљењима за национално ослобођење и обнављање српске државности. Српски грађански кругови у Трсту су посредно били укључени у процесе у Србији, што се подударало са појачаним интересовањем европске политике за Балкан.

У периоду од 1748. до 1781. године у Трст је пристигло нешто више од 150 православних хришћана с јужнословенског говорног подручја. ${ }^{3}$ Углавном су долазили из хервеговачког залеђа Османског царства. С подручја Херцег Новог и Боке Которске порекло је водио венецијански поданик гроф Јован Војновић. Јово Куртовић је био родом из Требиња, трговац скромног порекла који се у Трст доселио 1748. године. Из Требиња се доселио и Цветко Јовановић 1753. године, а нешто касније и Јован Ризнић из Сарајева. Половином 60-их година 18. века дошло је до већег прилива Срба у Трст који су се изјашњавали да су „из Требиња у Турској“. Јово Куртовић је постао власник брода 1766. године, али је већ управљао пловидбом великог броја изнајмљених бродова које је касније и откупио, превозећи робу од Трста

3 М. Дого, Нароg йобожних йрі̄оваца. Срӣско-илирска зајеgниияа y Трстиу 1748-1908, у: „Светлост и сенке“, приредила Марија Митровић, Клио, Београд 2008.

4 Исти, Исто. 
до представништава којима су управљала његова браћа у Измиру и Чешмеу у Турској, као и у Амстердаму, а пословао је и у Бечу и у Прагу, да би се касније путем трговине отиснуо и преко Атлантског океана. Срби у Трсту су трговали са Одесом, Петроградом, црноморским лукама, Скадром, Бечом, Пештом... Занимљив је пример заоставштине Србина из Трста Николе Петровића који је своју имовину завештао на више од 40 места у четири државе: манастиру у Јерусалиму, манастиру на Синају, манастиру на Светој Гори - Српска лавра, Манастиру на Светој Гори - Грчка лавра, Манастиру Дечани, Манастиру Девич, Манастиру у Ливну посвећеном Св. Петру, Манастиру Добрићево у Босни, Манастиру Студеница, Манастиру Пива, парохијској цркви у Сарајеву, Манастиру у Никшићу, самостану у Требињу, Манастиру Савина, Манастиру Св. Ђорђе у Рисну, Манастиру Паштровића, Манастиру Цетина, самостану Брчели у Црној Гори, самостану Острог, Манастиру Св. Стефан у Пиперима, Манастиру Морача, парохијској цркви Св. Ђорђа у Подгорици, Цркви у Спужу, цркви на Жабљаку, српској Цркви Св. Никола у Скадру, српској Цркви у Бару, Цркви у Васојевићима, Цркви у Зети, Цркви у Голубовцима, цркви у Плавници, Цркви у Понарима, српској Цркви Св. Николе у Ријеци. ${ }^{5}$ Србин из Трста Петар Паликућа финансирао је објављивање првог броја Физике Атанасија Стојковића. ${ }^{6}$

У различитим временским периодима, истим или различитим поводима, а најчешће вођени националним, културним и политичким циљевима, у Трсту су боравили: Доситеј Обрадовић, Атанасије Стојковић, Андрија Стојковић, Павле Соларић, Викентије Ракић, Димитрије Фрушић, Димитрије Владисављевић, Сима Милутиновић, Вук Караџић, Јоаким Вујић, Јефта Поповић, Петар

\footnotetext{
Исти, исто.

6 Исти, исто.
} 
Петровић Његош, Герасим Зелић, Лукијан Мушицки, Матија Бан, Љубомир Ненадовић, Милорад Медаковић, кнез Михаило Обреновић, краљ Александар Обреновић, краљ Никола Петровић, Јован Гавриловић, Светозар Марковић, а касније и Иво Андрић, и бројни други културни посленици и национални радници. Сви они су у својим мисијама на посебан начин деловали и утицали на Србе у Трсту који су били пореклом из Боке которске, Црне Горе, Босне, Херцеговине, Далмације.

Аустријске власти су се односиле према Србима у Трсту као према „илирској заједници“, како су иначе називали сопствене поданике православног словенског порекла. Средином 18. века досељени Срби заједно са Грцима основали су Православну црквену општину, у оквиру које је постојала и Православна црква. Рад Православне црквене општине правно је био заснован на Повељи царице Марије Терезије из 1751. године. Прва заједничка управа Општине основана је 1756. године, а за потпредседника је изабран Србин, Јован Војновић Следећа управа Православне црквене општине чији је председник био Јован Куртовић изабрана је 1757. године. ${ }^{8}$ Несугласице између Срба и Грка о питањима црквених послова довеле су до раскида заједнице 1781. године. На основу рескрипта цара Јосифа II одвојена српска заједница наставила је свој рад самостално и већ сле-

Јован Војновић (Giovanni Vojnovich) био је венецијански поданик пореклом с подручја између Херцег Новог и Боке которске а у Трст се са породицом доселио 1750. године. Видети: М. Дого, Нароg йобожних тиріоваияа. Срйско-илирска зајеgнииа у Трстй 1748-1908, у: Светилости и сенке (приредила: М. Митровић), Клио, Београд 2007, 62-63; М. Ал. Пурковић, Иситорија


Срйске йравославне ирквене ойшиичне у Трсииу 1749-1950, 1, Архив Србије, Београд 2007, 5.

8 Јово Куртовић, родом из Требиња, доселио се у Трст 1748. године. Истио. 
деће 1782. године њеним ангажовањем незванично је основана Српска школа у Трсту9. Српска школа је касније, када је и званично почела са радом 1792. године, добила назив Српска школа „Јован Милетић“ по имућном српском трговцу који је тестаментом од 1787. године завештао 24.000 форинти „Илирској заједници у Трсту“ с препоруком да се у Трсту оснује „завод за васпитање српске омладине“. ${ }^{10}$ Правно, српска заједница, односно Српска православна црквена општина у Трсту, свој рад уредила је Сйайуйом и Правилима (Statuti e Regolamenti dela Nazione e Confraternita Illirica stabilita nella citta e Portofranco di Trieste) одобреним од аустријске владе 1793. године којима су била регулисана питања Цркве, Школе и Црквене општине. Статут је остао на снази до 1950. године. ${ }^{11}$

Српска православна црквена општина и Српска школа „Јован Милетић“ биле су у дугом временском периоду места окупљања Срба који су ширили свест о националном идентитету, помагали српске уста-

9 Гроф Јован Војновић, Јово Куртовић, Јовица Ризнић и Јосиф Милетић 1. јануара 1782. године потписали су уговор са српским учитељем Василијем Витковићем да подучава српску децу читању, писању, граматици, латинском језику, певању и веронауци. - Архив Српске православне црквене општине у Трсту (у даљем тексту АСПЦО у Трсту), V. А. II ф. 178, бр. 252.

10 „Pianoformale“ - Устројство Српске школе у Трсту, 1. јануар 1792. АСПЦО у Трсту V. А. II, ф. 178, 338. у: АСПЦО у Трсту сачуван је превод тестамента на немачком и италијанском језику. АСПЦО у Трсту, V. А. IV, ф. 316. Детаљније о Српској школи „Јован Милетић“ у Трсту вид. А. Kos, Đ. Borovnjak, J. Reljić, La scuola serba 'Jovan Miletic' di Trieste 1782-1914, y: Genti di San Spiridone i Serbi a Trieste 1751-1914. Љygu Свет̄о̄ Cūupugона. Срби у Трсти 1751-1914, Silvana Editorial, Milano, Comune di Trieste 2009, 163-174.

11 М. Ал. Пурковић, н. д., 18-19; Архив Српске православне црквене општине у Трсту 1749-1950, Архив Србије, Београд 2007, 1, 5-6; А. Kos, Đ. Borovnjak, J. Reljić, н. д., 163. 
нике у борби за ослобођење од турске власти, пружали материјалну помоћ српским манастирима Хиландар, Грачаница, Дечани, Острог, развијали трговачке везе између унутрашњости Балканског полуострва и далеких тржишта. Српска православна црквена општина и Српска школа „Јован Милетић“у току 19. века израсле су у центре који су у значајној мери утицали на формирање духовног и културног живота Срба у Трсту који је био повезан са токовима развоја српске националне свести и догађајима у матици. Срби у Трсту су тежили да за своју школу ангажују што боље учитеље до којих су углавном долазили посредством карловачког митрополита. Будући да је школа све више добијала на значају, а свест да образовање има смисла била све развијенија, 1842. године је уследило доношење Устиава Срйске школе под називом Regolamento per le Scuole Slavo-Serbiche in Trieste, којим су била уређена сва битна питања за рад школе. ${ }^{12}$

Трст је у историји српског народа у различитим епохама имао различит значај. За прву генерацију досељених Срба у тај град, Трст је имао економску улогу. Већ следећа генерација крајем 18. и почетком 19. века оставила је печат у привредном животу и урбаној култури Трста $^{13}$ а посебно је имала значајну улогу у помагању српских устаника предвођених Карађорђем Петровићем, да би крајем 19. века, посебно после стицања независно-

12 Микрофилм рукописа на српском језику са насловом Устйви Србских училишћа у Триестй, 1-92, чува се у Универзитетској библиотеци у Београду. - УБС, М, 2/249.

13 Велики број најзначајнијих грађевина у Трсту које имају културну вредност саградили су Срби. То су: Палата Бајовић, Палата Вучетић, Палата Гопчевић, Палата Ивановић, Палата Куртовић, Палата Поповић, Палата Рађенковић, Палата Stella polare, Палата Цвијетовић, Палата Чевезић, Палата Шкуљевић, Кућа Српске заједнице и Храм Светог Спиридона. - Марианђела Албанезе, Срйске куће у Трстиу, у: Свейлости и сенке, Клио, Београд 2007. 
сти Србије (1878), Трст постао нека врста међународне осматрачнице српске владе и почео да добија све већи спољнополитички значај за српску државу. ${ }^{14}$ У годинама које су уследиле, у Србији су донети Закон о дийломайским засииуйнитивима и конзулатиима срйским у иносииранстиву (1879) и Правила конзулске службе (1882), a 1884. године у Трсту је основан Почасни конзулат Краљевине Србије. ${ }^{15}$ Указом краља Милана Обреновића од 24. фебруара 1884. године за првог почасног конзула постављен је Соломон Кабиљо. ${ }^{16}$ Новим Указом краља Милана Обреновића од 16. јула 1888. године установљен је Конзулат Краљевине Србије у Трсту, а за првог конзула у септембру исте године постављен је Иван Занковић. ${ }^{17}$ Следеће године је закупљен и стан за смештај Конзулата на првом спрату зграде у улици Лазарето векио (Via Lasaretto vechio). ${ }^{18}$ Конзулат у Трсту је Указом краља

14 О значају Трста за спољну политику Краљевине Србије вид. детаљније у: М. Перишић, Трси- - међународна осмайрачница Краљевине Србије, у: „Два века модерне српске дипломатије“, Зборник радова са Научног скупа „Два века модерне српске дипломатије“, (уредници: Чедомир Попов, Драгољуб Живојиновић, Слободан Г. Марковић), Балканолошки интитут САНУ и Институт за европске студије, Београд 2013, стр. 137-144.

15 Извештај о почетку рада Конзулата - АС, МИД, К-Т, ф. 1, p. 3/1884.

16 АС, НС, ф. 2, p. 44/1878; АС, МИД-А, ф. 22, p. 111/1883; АС, МИД-А, ф. 28, р. 5/1884; АС, МИД-А, 2105/1884; С. Поповић, Кральевско-срйски іенерални конзулай у Трсий (1888-1914), у: Архивски преглед 1-2, Београд 1991, 29- 31.

17 АС, МИД-А, ф. 14, p. 6/1888; АС, МИД, К-Т, ф. 1, p. 29/1888; С. Поповић, Истй

18 У мају 1889. године склопљен је Уговор о закупу стана за српски Конзулат у Трсту између Милене Константиновић Опуић, члана Српске општине и конзула Ивана Занковића. Уговор о закупу стана за српски Конзулат у Трсту сачуван је у извештају Ивана Занковића, упућеном министру иностраних дела Краљевине Србије, Сави Грујићу, 29. маја 1889. - АС, МИД-А, ф. 2, р. 8/1893. На основу података које је Јелица Рељић, архивски саветник у Архиву Србије и руководилац пројекта сређивања и обраде 
Александра Обреновића од 16. априла 1894. године подигнут у ранг Генералног конзулата. ${ }^{19}$ Од 1913. до 1914. године радио је поново под називом Конзулат Краљевине Србије у Трсту. ${ }^{20}$ Рад Конзулата прекинут је 1914. године, а после Првог светског рата наставио је рад под називом Конзулат Краљевине Срба, Хрвата и Словенаца, када је у једном краћем периоду у конзулату радио и Иво Андрић. ${ }^{21}$

У периоду од 1884. до 1914. године дужност почасних конзула, конзула и генералних конзула, у зависности од ранга Конзулата, обављали су: Соломон Кабиљо, Иван Занковић, Марко Мариновић, Петар Карастојановић, Бранко Мушицки, Јован Христић, Хаим Давичо, Милосав Куртовић, Корнелијус Ритер фон Горуп и Милан Милојевић. ${ }^{22}$

Велики број извештаја српских конзула у Трсту сачуван је у Архиву Србије. Њихова неуједначеност према садржају, изворној вредности, обиму и учесталости, резултат је ондашњих прилика, честих промена ранга Конзулата, личности самих конзула и захтева мини-

архивске грађе у Архиву Српске православне црквене општине у Трсту, истражила на основу података пронађених у Guida generale per Trieste 1898, 522, утврђено је да су се 1898. године српски и француски конзулати налазили на првом спрату исте зграде.

19 АС, МИД, К-Т, ф. 2 р. 93/1894. Саопштење Министарства иностраних дела Краљевине Србије од 19. априла 1894. године о постављењу генералног конзула и подизању ранга Конзулата у ранг Генералног конзулата.

20 С. Поповић, н. д., 31.

${ }_{21}$ Зборник закона и уреgаба Кратьевине Србије, књ. 50, 40.

22 Видети у: Истиорија сритске gийломайије - gокуменйа, књ. 1. Генерални конзулати Кратевине Србије у Трсииу 1884-1914 (приредили: М. Перишић, С. Рајак, Ј. Рељић), Архив Србије, Београд 2009. I Storia della diplomazia serba. Documenti. Consolato generale del Regno di Serbia a Trieste 1884-1914 (Redazione di: Miroslav Perišić, Svetozar Rajak, Jelica Reljić, Archivio della Serbia, Belgrado 2009; Шематиизам Кратевине Србије 1884-1914. 
стара иностраних дела Краљевине Србије. ${ }^{23}$ Изворно најдрагоценији су петнаестодневни извештаји генералног конзула Хајима Давича од 1898. до 1900. године. На садржајност и редовност извештаја утицала је сама држава, односно Министарство иностраних дела Краљевине Србије. Тако је, на пример, расписом од 7. новембра 1895. године, тадашњи министар иностраних дела Стојан Новаковић скренуо пажњу шефовима краљевских мисија у иностранству да је „преко потребно да се сакупљање вести и њихово слање организује и врши у одређено време, редовно и тачно“. Стојан Новаковић је захтевао од шефова краљевских мисија да петнаестодневно достављају „рапорте“ Министарству о свему што се догађа у тој држави. Будући да овај захтев није у потпуности био поштован, Владан Ђорђевић, министар председник и министар иностраних дела, 6. јануара 1898. године упутио је распис „свим краљевским посланицима, дипломатском агенту у Софији, отправницима послова у Атини и Риму и свим генералним конзулима и вицеконзулима" да редовно сваког првог и петнаестог у месецу шаљу извештаје о свему што се догађа у држави где се наименовани налази и да свако „одабере оно што може бити од нарочитог интереса по Министарство“, да у тим извештајима посвете што више пажње личној процени догађаја „према личном посматрању и праћењу“, да се „постарају да о свему интересантнијем имају што више сопствених

23 Највећи број извештаја сачуван је за период када је конзул био Хајим Давичо. За периоде од 1884. до 1888. и од 1902. до 1914. године сачуван је мали број докумената. У регистрима МИД-ПО где су заведени сви оригинални конзулски извештаји за период од 1903. године не постоје одреднице које би упућивале да су извештаји слати из Трста у Београд. У архивској грађи Генералног конзулата у Трсту за период од 1903. до 1907. није сачуван ниједан документ, а за период од 1908. до 1914. године сачувана су само 4 листа. 
Српско грађанство у Трсту и „балкански трошан свет“... 133

информација, да би извештаји добили потребну вредност“" и да се са извештајима „почне одмах“.24

Захваљујући сачуваним петнаестодневним извештајима Хајима Давича може се закључити да је Трст имао велики значај у спољној политици Краљевине Србије крајем 19. и почетком 20. века, односно да је Београд добијао изузетно велики број информација посредством Конзулата у Трсту. У извештајима се налазе информације не само о политичким, економским и друштвеним приликама у Трсту и о српској православној заједници, већ и подаци о писању тршћанских листова о политичким приликама у Србији и о збивањима у Аустро-Угарској. Поглед из Трста сеже до западних граница Турског царства, Босне и Херцеговине, Црне Горе, Албаније. У извештајима се налази прегршт података о најразличитијим темама. Генерални конзул Краљевине Србије у Трсту извештавао је о раду покрајинских сабора, перспективи трговачких односа Трста и Србије, свечаностима поводом националних и државних празника, приликама у Далмацији и Истри, изградњи железница и пловних канала, присуству и деловању аустроугарске морнарице у Боки и Далмацији, католичком свештенству, епидемијама, српском покрету у Босни и Херцеговини, политичкој пропаганди, боравку значајних личности у Трсту, страним агентима, словенским покретима, војним маневрима, школама, универзитету, стању у самом Конзулату. Импресиван је списак тема, политичких и других вести, значајних војних информација и личних запажања конзула које је српска краљевска влада у Београду добијала из Трста крајем 19. и на самом почетку 20. века. Генерални конзул је извештавао: о покретима у Албанији, о српском омладинском покрету у Херцеговини, о ширењу немачке пропаганде у Трсту, о ставу Бењамина Калаја о

24 АС, МИД, ПО, Ц-1, ф. 13/1898. 
меморандуму депутације Мостараца у Бечу, о путовању немачког генералног конзула у Трсту по Албанији, о гласовима о предстојећем одласку црногорског кнеза у Петроград, о сметњама за трговину између Србије и Црне Горе, о одјецима ослобађања Николе Пашића, о арнаутским покретима на црногорској граници, о словенским народним покретима у Истри, Крањској и Штајерској, о прослави рођендана краља Александра Обреновића у Трсту и о прослави рођендана Фрање Јосифа у Трсту, о ставовима словенофила у приморју према Србији, о припремама за маневре сувоземне војске и ратне морнарице код Оршаве, о утисцима тршћанских трговаца са путовања по Србији, о путовању Бењамина Калаја по Босни и Херцеговини, о трговини у Скадру, о оснивању бугарских банака на тршћанској берзи, о Трсту у светлу аустроугарске железничке и уопште саобраћајне политике, о заступницима страних држава на Цетињу и њиховим активностима у Дубровнику, о потреби упућивања представника српске владе у Дубровник ради информисања о интересним сферама Аустро-Угарске, Италије и Црне Горе, о утицају куге у Александрији на трговину у Трсту, о одзиву Арнаута за упаде преко српске границе, о Србима у Задру, о порасту хајдучије у Црној Гори, о бившем турском конзулу Фичу у Земуну и његовом пријатељском расположењу према Србији, о нападима на Србе у Санџаку и савезништву Беча са српским противницима, о митингу албанских вођа и старешина у Пећи... Сачувани су и извештаји: о писању тршћанских листова о Србији и краљевском двору, о друштвеном животу у Трсту, прославама Светог Саве међу Србима у Трсту, о забавама и баловима, осигуравајућим друштвима, о производњи и експлоатацији сувих шљива, о злоупотребама српских увозника вина, о уметницима, глумцима, новинарима и листовима, о вестима из Цариграда које стижу до Трста, о разлозима боравка угледних личности у Трсту, о напо- 
рима Српског певачког друштва „Слога“ из Дубровника у борби за очување српске народности, о политичким врењима у Бечу, о аутономији Српске православне црквене општине у Трсту, о свештеницима у Српској цркви у Трсту, о набавци књига за Српску школу у Трсту, о верској настави у Српској православној цркви у Трсту, о везама Срба из Трста са сународницима у другим државама и градовима, посебно са Србима у Дубровнику. ${ }^{25}$

Бројни и садржајни извештаји српских дипломатских представника у Трсту крајем 19. и почетком 20. века имали су велики значај за српску владу у Београду у њеним напорима да прати догађаје на Балкану и ширем окружењу о веома битним питањима за спољну политику Србије. Генерални конзулат Краљевине Србије у Трсту, између осталог, извештавао је и о боравку у Трсту српског краља Александра Обреновића 1896. године:

„Његово Величанство Краљ стигао амо синоћ из Сењске Реке железницом у 8.51 сах. у вече у најповољнијем здрављу. Вице-консул изишао Му на сусрет до Набрежине. Ма да Краљ путује инкогнито дочекао га је на станици намесник Круновине Трста, подеста, директор полиције, српска колонија и мноштво народа, које је Краља поздравило бурним 'живео' и 'евива'. Данас у 10 $1 / 2$ сах. Његово Величанство благизоволело је походити српску цркву, где је свечано дочекано. Свештенство у орнату одслужило молепствије. За тим се Краљ одвезао, да походи арсенал." Следећег дана уследила је депеша: „Његово Величанство Краљ благоизволело је јуче после подне извести се у дворац Мирамар и разгледати га, а у вече присуствовати представи у варошком позоришту. Данас пре подне прегледао је Револтелин варошки музеј.

25 О везама Срба у Трсту са Србима у Дубровнику детаљније у: Кулйура Срба у Дубровнику 1790-2010. (приредили: Г. Спаић, J. Рељић, М. Перишић), Архив Србије - Срӣска йравоставна ирквена оититинна у Дубровнику, Београд-Дубровник 2012, 425. 
После подне шетња у вилу Аурору. У вече у 8 сах. повратак у Београд преко Будапеште“. 26

Извори:

Архив Србије, МИД ПО

Архив Српске православне црквене општине у Трсту, Стара архива

\section{Основна литература:}

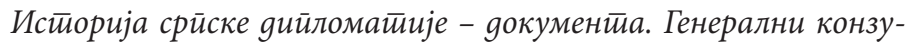
лати Кратевине Србије у Трсииу 1884-1914, друго издање / StoriadelladiplomaziaserbaDocumenti, ConsolatoGenrale del Regno Regno di Serbia a Trieste 1884-1914, Secondaedizione, приредили: М. Перишић, С. Рајак, J. Рељић, Архив Србије, Београд 2013.

Кулитура Срба у Дубровнику 1790-2010. (приредили: Г. Спаић, J. Рељић, М. Перишић), Архив Србије - Срӣска ирравославна ирквена ойшичина у Дубровнику, Београд-Дубровник 2012.

Марко Дого, Нароg йобожних тиріоваца. Срииско-илирска зајеgница у Трсти $1748-1908$, у „Сенке и светлости“ приредила Марија Митровић, Клио, Београд 2008.

Миодраг Ал. Пурковић, Истиорија Срйске ирравославне ирквене

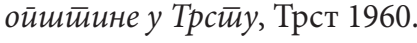

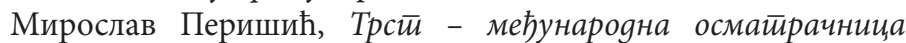
Краљевине Србије, у: „Два века модерне српске дипломатије“, Зборник радова са Научног скупа „Два века модерне српске дипломатије“, (уредници: Чедомир Попов, Драгољуб Живојиновић, Слободан Г. Марковић), Балкано-

26 Извештај и депеша Генералног конзулата Краљевине Србије у Трсту од 8. и 9. априла 1896. године; АС, МИД, К-Т-Ф. 1 р. 137/1896; Истиорија срйске gийломаииије - gокуменииа. Генерални конзулай Кратевине Србије у Трстиу 1884-1914, друго издање / Storia della diplomazia serba Documenti, Consolato Genrale del Regno di Serbia a Trieste 1884-1914, Secondaedizione, приредили: М. Перишић, С. Рајак, Ј. Рељић, Архив Србије, Београд 2013, 125-126. 
Српско грађанство у Трсту и „балкански трошан свет“... 137

лошки интитут САНУ и Институт за европске студије, Београд 2013.

Мита Костић, Срӣско йрїовачко насеље у Трстиу XVIII века, Историски часопис, V (1954-1955), Београд 1955.

Радован Самарџић, Срби у Турском иарсииву 1699-1716, у: „Историја српског народа“, Београд 1986.

Сенке и светлост, приредила Марија Митровић, Клио, Београд 2008.

\section{Сажетак}

Срби у Трсту нису имали неку своју независну историју. Пословима и културом живљења били су интегрисани у тршћанско друштво на чији је развој и укупни преображај, који је започео почетком 18. и трајао до краја 19. и почетка 20. века, пресудни утицај имала политика Хабзбуршке монархије према овој северној јадранској пуци и највећем трговачком центру тог дела Јадрана. Трст је био под влашћу, или, како то поједини историчари пишу, под заштитом Хабзбуршке монархије, па је политика Царства према Трсту, утицала и на многе аспекте живота Срба у том граду. Марија Терезија је имала и директан утицај на положај Срба односно „илирске заједнице“ у Трсту. Срби у Трсту су били зачетници српског грађанства пре него што је почела обнова српске државности у 19. веку, а Трст је био једно од најзначајнијих духовних средишта Срба ван Србије. Завршетком 19. и почетком 20. века завршило се и раздобље значајније улоге Срба у историји Трста. Трст је кроз модерну историју био надахнуће српским писцима и песницима као један од центара духовне обнове Срба. Историја српског грађанства никако не би могла да мимоиђе историју Срба у Трсту. 


\title{
Miroslav Perišić
}

\author{
SERBIAN BOURGEOISIE IN TRIESTE AND \\ BALKAN RAMSHACKLE WORLD: \\ BRIDGE TO THE SPIRITUAL AND STATE RENEWAL \\ OF SERBIA IN THE $18^{\mathrm{TH}}$ AND $19^{\mathrm{TH}}$ CENTURIES
}

\begin{abstract}
Summary
The paper analyzes the emergence and development of Serbian bourgeoisie in Trieste in the period when Serbia was still under the Turkish authorities and the influence of Trieste as the spiritual center of Serbs beyond the borders of Serbia, ie the Serbs in Trieste, on the spiritual and later state reconstruction of Serbia. The work also contains a certain periodization of the significance of Trieste for the history of Serbia, especially in the 18th and 19th centuries, ie three components: the preservation of religious and cultural identity, the strengthening of the national identity and the political importance of Trieste for the foreign policy of the Kingdom of Serbia.

Key words: Trieste, Serbs in Trieste, Serbian bourgeoisie in Trieste, religious identity, economic power, help for the Serbian monasteries and churches, assistance to the rebels against the Turkish authorities, Consulate General of the Kingdom of Serbia in Trieste, political significance of Trieste for the Kingdom of Serbia
\end{abstract}

